MatgoRZata Kosata

Uniwersytet Ekonomiczny w Krakowie, Polska - Cracow University of Economics, Poland

\title{
Przedsiębiorczość imigrantów w państwach UE i krajach OECD
}

\section{Immigrant Entrepreneurship in the EU and OECD Countries}

\begin{abstract}
Streszczenie: Uwarunkowania rozwoju współczesnej gospodarki wiążą się z procesami globalizacyjnymi. Jednym z kluczowych elementów takiej gospodarki są migracje. Decyzja o emigracji wymaga przełamania wielu barier, podjęcia ryzyka. Wyzwaniem staje się funkcjonowanie w nowych warunkach społeczno-gospodarczych, gdzie każde podjęte działanie nacechowane jest innowacyjnością. Można postawić tezę, że działania takie wymagają od emigrantów rozwiniętych zachowań przedsiębiorczych. Połączenie zjawisk, takich jak migracje i przedsiębiorczość, a w konsekwencji analiza przedsiębiorczości imigrantów staje się interesującym polem badawczym. Celem głównym opracowania jest analiza zjawiska przedsiębiorczości wśród imigrantów oraz określenie istotnych obszarów dla dalszych prac badawczych. W ramach tak określonego celu poruszono zagadnienia odnoszące się do zachowań przedsiębiorczych oraz problematyki migracji. Dla potrzeb realizacji celu wykorzystano dostępną literaturę przedmiotu. Odczuwa się pewien niedosyt w zakresie prowadzonych badań, szczególnie pogłębionych, kompleksowych. W niektórych krajach (np. Grecja) można zauważyć wyższy wskaźnik samozatrudnienia wśród rdzennych mieszkańców, natomiast w innych (np. Polska) wśród imigrantów. Można przypuszczać, że na taki obraz mają wpływ z jednej strony bariery przedsiębiorcze dla emigrantów (kapitał, ograniczenia formalno-prawne), a z drugiej skłonność rodzimych mieszkańców do prowadzenia własnej firmy. Powstaje pytanie, na ile te różnice są wynikiem zachowań przedsiębiorczych, ograniczeń formalno-prawnych, wymuszonej przedsiębiorczości. Poznanie motywów migracji wśród przedsiębiorców imigrantów, z uwzględnieniem narodowości imigrantów oraz branży, w której działają w poszczególnych krajach, pozwoliłoby na formułowanie precyzyjnych wniosków.
\end{abstract}

Abstract: Determinants of the development of modern economies are associated with globalization processes. One of the key elements of the new economy is migrations. Decisions about migration require overcoming many challenges. The functioning in the new socio-economic conditions becomes challenging, whereas every action is connected with innovation. It can be argued that it requires immigrants to be more entrepreneurial. The combination of phenomena such as migration and entrepreneurship, and consequently the analysis of immigrant entrepreneurship, is becoming an interesting research field. The main objective of the study is to analyze the phenomenon of entrepreneurship among immigrants and to identify important areas for further research in this field. As part of that objective, the article addresses issues related to entrepreneurial behavior and migration. The article is based on available literature review. We can observe some in-depth comprehensive deficiency in the literature. In some countries (e.g. Greece), you will notice a higher rate of self-employment among indigenous people, in others (e.g. Poland) among immigrants. It can be assumed that such a picture is affected on the one hand by the barriers towards entrepreneurial immigrants (capital, legal constraints) and 
on the other, by the tendency of native residents to run their own businesses. The question is to what extent these differences are the result of entrepreneurial behavior, constraints, formal and legal, forced entrepreneurship. Ascertaining the reasons for migration among immigrant entrepreneurs, including the immigrant nationalities and the industry in which they operate in individual countries, would allow to formulate proper conclusions.

Słowa kluczowe: migracja; przedsiębiorczość; przedsiębiorczość imigrantów

Keywords: entrepreneurship; immigrant entrepreneurship; migration

Otrzymano: 11 stycznia 2016

Received: 11 January 2016

Zaakceptowano: 12 maja 2016

Accepted: 12 May 2016

\section{Sugerowana cytacja/Suggested citation:}

Kosała, M. (2016). Przedsiębiorczość imigrantów w państwach UE i krajach OECD. Przedsiębiorczość Edukacja, 12, 326-340.

Wstęp

Współczesne uwarunkowania gospodarcze powinny być rozpatrywane w kontekście wszechobecnych procesów globalizacyjnych. Rozwój technologii informacyjno-komunikacyjnej, którego skutkiem jest łatwy dostęp do informacji oraz duża możliwość pozyskiwania wiedzy i jej weryfikacji, wpływa na globalne postrzeganie przestrzeni społeczno-gospodarczej. Możliwość pozyskiwania wszelkich zasobów w warunkach globalnych i wykorzystanie tej szansy przełożyły się na nawiązywanie i rozwój współpracy międzynarodowej. W ślad za rozwojem tej współpracy na gruncie gospodarczym zmianom ulegały uwarunkowania polityczno-prawne, które wpłynęły na liberalizację przepisów o ruchu granicznym, by w rezultacie, jak w przypadku krajów należących do strefy Schengen, pozwolić na swobodny przepływ osób wewnątrz strefy, który dotyczy nie tylko obywateli tych państw, lecz wszystkich osób przekraczających granice wewnętrzne na terenie objętym porozumieniem (wszelkiej narodowości i o dowolnym obywatelstwie).

Procesy migracyjne, które od zawsze występowały i które są jak najbardziej naturalnym zjawiskiem, stają się współcześnie coraz intensywniejsze. Głównych przyczyn migracji można upatrywać w różnicach dotyczących sytuacji gospodarczej (np. polepszenie warunków materialnych) lub politycznej (np. zagrożenie działaniami wojennymi, dyskryminacja wyznaniowa).

Decyzja o emigracji i jej realizacja stanowi spore wyzwanie. Wiąże się z przełamaniem wielu barier, podjęciem pewnego ryzyka czy zaangażowaniem kapitału. Można postawić tezę, że działania takie wymagają od emigrantów rozwiniętych zachowań przedsiębiorczych. Ponadto nie mniejszym wyzwaniem dla obcokrajowców staje się umiejętne funkcjonowanie w nowych warunkach społeczno-gospodarczych, gdzie każde podjęte i zrealizowane działanie nacechowane jest innowacyjnością. Przedsiębiorczość jest jednym ze sposobów odnalezienia się w nowych warunkach, a analiza problematyki przedsiębiorczości wśród imigrantów staje się interesującym zagadnieniem badawczym. W opracowaniu odniesiono się zarówno do zagadnień migracji, jak i przedsiębiorczości.

Celem głównym podjętych badań, realizowanych w oparciu o wykorzystanie dostępnej literatury przedmiotu jest analiza zjawiska przedsiębiorczości wśród imigrantów oraz określenie istotnych obszarów dla dalszych prac badawczych w tym zakresie. 


\section{Zachowania przedsiębiorcze}

Przedsiębiorczość można rozpatrywać w kontekście zjawiska ekonomicznego, społecznego, jak również w zakresie zarządzania (Glinka, Gudkova, 2011). Definicje przedsiębiorczości w literaturze przedmiotu odnoszą się do (Wach, 2013; 2015a):

- rynku, czyli działań przedsiębiorczych w gospodarce,

- osobowości, tj. cech osobowych przedsiębiorców,

- czynności menedżerskich, czyli specyficznego sposobu zarządzania,

- indywidualnego przedsiębiorcy.

Istota przedsiębiorczości sprowadza się do umiejętności wyszukiwania szans i okazji rynkowych oraz ich aktywnego wykorzystania, z uwzględnieniem ryzyka, jakie jest z tym związane (ujęcie procesowe). Skutkiem działań przedsiębiorczych jest uzyskanie wyższej efektywności w ramach dostępnych zasobów, a przedsiębiorczość utożsamiana jest z procesem tworzenia nowej wartości. Przedsiębiorczość związana jest z cechami i zachowaniami osób, jest kwestią praktyki i motywacji (Targalski, Kosała, Pichur, 2007: 90). W centrum uwagi staje zatem osoba - przedsiębiorca, który wykazuje się szczególnymi cechami i umiejętnościami pozwalającymi na podejmowanie tego rodzaju działań (ujęcie osobowościowe).

Wśród cech charakteryzujących osoby podejmujące działania przedsiębiorcze i składających się na postawę przedsiębiorczą można wymienić: inicjatywę, przywództwo, komunikatywność, umiarkowaną skłonność do ryzyka, elastyczność, pomysłowość, kreatywność, umiejętność przewidywania, zdolność podejmowania decyzji, niezależność, pozytywne nastawienie do krytyki, optymizm, potrzebę osiągnięć, wytrwałość, optymizm, umiejętność rozwiązywania problemów, spostrzegawczość i wyobraźnię (Gibb, 1990; Drucker, 1991; Piasecki, 1997; Domurat, 2011).

Przedsiębiorczość odnosi się do przedsiębiorcy, czyli osoby prowadzącej działalność gospodarczą, ważnego uczestnika systemu społeczno-gospodarczego (aspekty prawne, rola w gospodarce, zakres działania), wyróżniającego się najczęściej przedsiębiorczymi cechami (problematyka dotycząca cech osobowych) i realizującego przedsięwzięcia (specyficzny sposób zarządzania, ukierunkowany na podejmowanie szans rynkowych i wprowadzanie innowacji) w przedsiębiorstwie (jednostka gospodarcza prowadząca działalność gospodarczą). Jest to uproszczenie zagadnienia, jednak pozwala ono na pokazanie jego złożoności definicyjnej (Kosała, 2014). Wspieranie przedsiębiorczości umożliwia optymalizowanie korzyści w zakresie prowadzenia firmy. Wpływa również na aktywne kształtowanie kariery zawodowej oraz osiąganie odpowiedniej pozycji społecznej poprzez umiejętne, efektywne lokowanie zasobów (Kosała, Pichur, 2008).

Aby zrozumieć, jakie mechanizmy rządzą intencjami przedsiębiorczymi poszczególnych jednostek, warto wykorzystać koncepcję psychologiczno-socjologiczną pochodzącą z połowy lat 80. XX w., opracowaną przez I. Ajzena (1991) - teorię planowanego zachowania (ang. theory of planned behavior, TPB), zgodnie $\mathrm{z}$ którą intencje zachowania zależą od trzech antecedencji: od tego, jakie mamy do tego zachowania nastawienie, od postrzeganej kontroli zachowania, czyli wykonalności, oraz od norm społecznych, które kształtują postrzeganie tego zachowania (Wach, 2015b). 


\section{Migracje a przedsiębiorczość}

Ciekawym problemem badawczym staje się połączenie przedsiębiorczości ze zjawiskiem migracji. Imigranci stanowią bowiem specyficzną grupę społeczną, która charakteryzuje się skłonnością do podejmowania aktywności związanej z wysokim stopniem niepewności i ryzyka, jaką jest decyzja o osiedleniu się w obcym kraju.

Skłonność do migracji można wyrazić jako funkcję dwóch zmiennych: akceptowalności ryzyka oraz odczuwanej pozycji społecznej (ryc. 1).

Ryc. 1. Skłonność osób do migracji

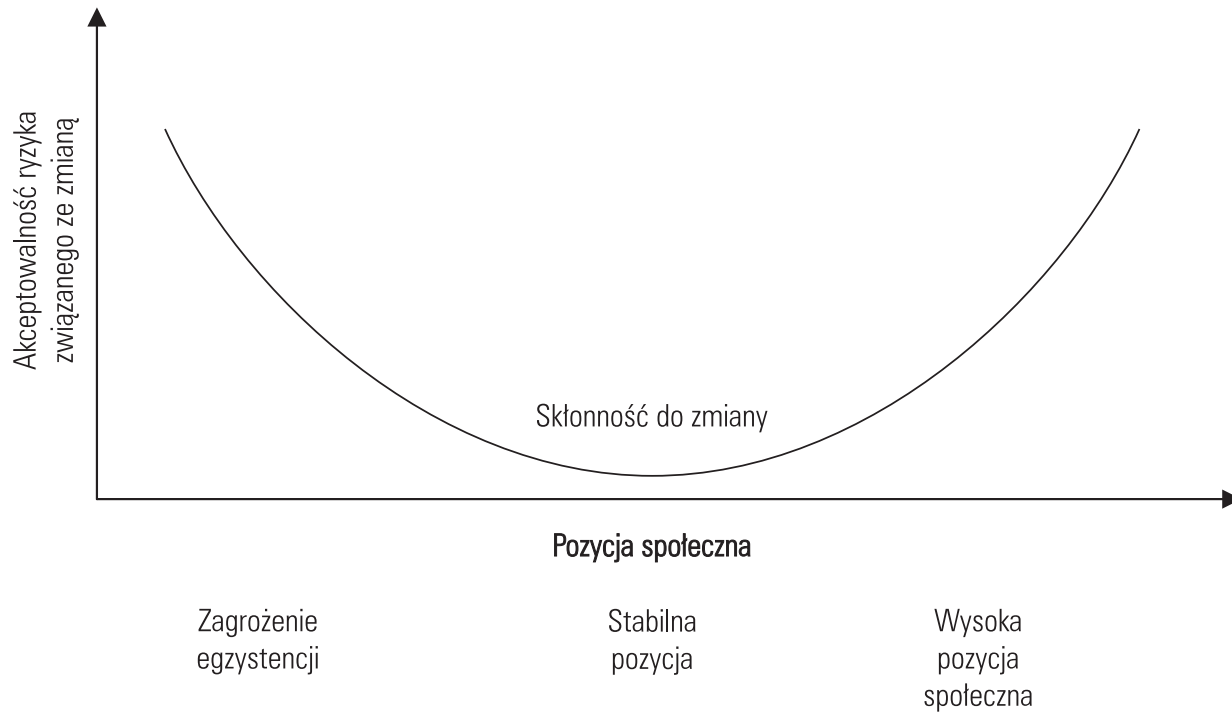

Źródło: opracowanie własne

Skłonność do podejmowania ryzykownych działań w zależności od zajmowanej pozycji społecznej, przy określonym poziomie ryzyka, jest wysoka w sytuacji zagrożenia egzystencji (migracje ekonomiczne) i maleje wraz ze stabilizacją pozycji społecznej, aż do jej unormowania. W przypadku osób o stabilnej pozycji skłonność ta osiąga swój punkt krytyczny (minimum) i jest to sytuacja, która zachęca do utrzymania status quo. W miarę wzrostu pozycji społecznej osoby chętniej podejmują działania migracyjne, przy czym z zupełnie innych powodów (migracje poznawcze, turystyczne). Można przyjąć, że we współczesnych warunkach migracje będą się nasilały, a przedsiębiorczość pozwoli na efektywniejszą asymilację w nowej społeczności.

Migracje - modele, znaczenie w gospodarce

Słowo „migracja” pochodzi od łacińskiego wyrazu migratio i oznacza przesiedlenie, a szczegółowiej - demograficzne wędrówki albo ruch mechaniczny (fizyczny) ludności, czyli przemieszczenia terytorialne związane ze względnie trwałą zmianą miejsca zamieszkania (Internetowa encyklopedia $P W N$ ). Można wskazać wiele rodzajów migracji, posługując się wybranymi kryteriami. Ze względu na kryterium (Internetowa encyklopedia PWN): 
a. czasu wyróżnia się migracje:

- stałe (trwała zmiana miejsca zamieszkania),

- czasowe (sezonowa lub okresowa zmiana miejsca zamieszkania),

- wahadłowe (codzienne dojazdy z miejsca zamieszkania do miejsca pracy lub nauki);

b. odległości rozróżnia się migracje:

- wewnętrzne (w obrębie danego państwa - wewnątrzregionalne lub międzyregionalne),

- zewnętrzne (poza granice państwa - kontynentalne, międzykontynentalne);

c. organizacji można wyróżnić migracje:

- żywiołowe, planowe (np. repatriacje),

- legalne,

- nielegalne,

- dobrowolne,

- przymusowe (przesiedlenia, wysiedlenia, deportacje);

d. przyczyny migracje dzieli się na:

- zarobkowe,

- rodzinne,

- narodowościowe,

- religijne,

- polityczne,

- edukacyjne,

- rekreacyjne,

- turystyczne.

Biorąc pod uwagę kierunki napływu ludności, wyróżnia się imigrację, która oznacza napływ ludności na dane terytorium, natomiast jej odpływ określany jest jako emigracja. Reemigracja zaś to powrót do dawnego miejsca zamieszkania (migracja powrotna).

Badania ludzkich migracji zostały zdominowane przez naukowców antropologii (dane pochodzą z wielu dyscyplin, tj. z archeologii, etnologii, antropologii kulturowej, a opracowane modele mają tendencję do skupiania się na początkach społeczeństwa), historii i socjologii. Socjologiczne podejście do analizy zjawiska migracji zaowocowało opracowaniem licznych teoretycznych modeli koncentrujących się na zjawiskach ekonomicznych, demograficznych, społecznych czy politycznych, które w znacznym stopniu się pokrywają. Funkcjonujące obecnie teorie migracji podejmują próbę odpowiedzi na pytania: kto, dlaczego i gdzie migruje oraz jakie są następstwa tego procesu (Clark, 1986; J. Lucassen i in., 2010; Holobinko, 2012). Główne zainteresowania badawcze poruszające problematykę migracji odnoszą się do (Portes, Bach, 1985 za: Włoch, 2015):

- genezy migracji,

- kierunku i ciągłości przepływów migrantów,

- wykorzystania imigranckiej siły roboczej,

- społeczno-kulturowej adaptacji imigrantów.

Wśród wypracowanych teorii, modeli migracyjnych (tab. 1), można wyróżnić takie, które zwracają uwagę na czynniki negatywne - „wypychające” z kraju macierzystego mieszkańców, czynniki korzystne - „przyciągające” imigrantów do danego kraju, elementy gospodarki pozwalające na maksymalny zwrot $\mathrm{z}$ inwestycji czy też wynikające z korzystania z sieci społecznych, jak również takie, które odnoszą się do chęci pozyskiwania nowych doświadczeń, motywów poznawczych oraz swobody wyboru miejsca zamieszkania w świecie „bez granic”. O ile początki migracji były determinowane czynnikami ekonomicznymi i również aktualnie mają 
istotne znaczenie, o tyle warto zwrócić uwagę na kwestie migracji wynikające z chęci świadomego wyboru miejsca zamieszkania rozważanego w kontekście globalnym (np. migracje emerytów niemieckich czy mieszkańców Skandynawii do cieplejszych rejonów świata).

Tab. 1. Przegląd głównych teorii/modeli migracyjnych

\begin{tabular}{|c|c|c|}
\hline Teoria/Model & Podstawowe założenia & Mankamenty \\
\hline $\begin{array}{l}\text { Teoria neoklasyczna: } \\
\text { push and pull (Lee, 1966) } \\
\text { poziom analizy: makro }\end{array}$ & $\begin{array}{l}\text { Zachowanie migranta jest racjonalne w wymiarze } \\
\text { jednostkowym. O migracji decydują czynniki } \\
\text { wypychające (np. niemożność znalezienia pracy } \\
\text { w miejscu zamieszkania, niesatysfakcjonujące } \\
\text { dochody, niemożność realizacji ambicji } \\
\text { i planów życiowych) i przyciągające (możliwość } \\
\text { znalezienia pracy, lepsze zarobki, poziom życia, } \\
\text { możliwość podniesienia kwalifikacji). } \\
\text { Nacisk został położony na indywidualny wybór } \\
\text { migranta. } \\
\text { Teorię tę uważa się za archaiczną, ale nadal } \\
\text { funkcjonuje i poddawana jest wielokrotnym } \\
\text { modyfikacjom; silnie opiera się na teorii } \\
\text { racjonalnego wyboru. }\end{array}$ & $\begin{array}{l}\text { Nadmierne } \\
\text { uproszczenie } \\
\text { czynników migracji, } \\
\text { brak hierarchizacji } \\
\text { czynników. }\end{array}$ \\
\hline $\begin{array}{l}\text { Teoria neoklasyczna } \\
\text { kapitału ludzkiego } \\
\text { (Sjaastad, 1962) } \\
\text { poziom analizy: mikro }\end{array}$ & $\begin{array}{l}\text { Migranci dążą do maksymalnego zwrotu } \\
\text { z inwestycji (np. w przypadku migrantów } \\
\text { edukacyjnych - do zwrotu inwestycji } \\
\text { w edukację). Umożliwia im to wysoki poziom } \\
\text { kapitału ludzkiego (cech wrodzonych, wiedzy, } \\
\text { umiejętności i doświadczenia). }\end{array}$ & \begin{tabular}{|l|} 
Przecenianie \\
„racjonalności” \\
i dobrowolności \\
decyzji o migracji.
\end{tabular} \\
\hline $\begin{array}{l}\text { Teoria dualnego rynku } \\
\text { pracy (Reich, Gordon, } \\
\text { Edwards, 1973) } \\
\text { poziom analizy: mezo }\end{array}$ & $\begin{array}{l}\text { Kluczowe znaczenie mają czynniki przyciągające } \\
\text { po stronie państwa przyjmującego (zwłaszcza } \\
\text { charakterystyka rynku pracy). } \\
\text { W ramach rynku pracy funkcjonują dwa } \\
\text { segmenty: } \\
\text { 1) zapewniający pracę, relatywnie wysokie } \\
\text { wynagrodzenia i możliwości awansu zawodowego } \\
\text { osobom wysoko wykwalifikowanym; } \\
\text { 2) zatrudniający osoby niżej wykwalifikowane, } \\
\text { oferujący niższe wynagrodzenia i mniejsze } \\
\text { możliwości awansu zawodowego (w tym } \\
\text { segmencie częściej pracują imigranci). }\end{array}$ & $\begin{array}{l}\text { Arbitralny podział } \\
\text { na } 1 \text { i } 2 \text { segment, } \\
\text { nadmierne } \\
\text { skupienie na kraju } \\
\text { przyjmującym. }\end{array}$ \\
\hline $\begin{array}{l}\text { Teoria etnicznej enklawy } \\
\text { na rynku pracy (Portes, } \\
\text { Bach, 1985) } \\
\text { poziom analizy: mezo }\end{array}$ & $\begin{array}{l}\text { W krajach przyjmujących imigrantów powstają } \\
\text { etniczne enklawy zapewniające im pracę, często są } \\
\text { one równoległe wobec rynku pracy i funkcjonują } \\
\text { w dużej mierze w szarej strefie. }\end{array}$ & $\begin{array}{l}\text { Przecenianie izolacji } \\
\text { etnicznego rynku } \\
\text { pracy. }\end{array}$ \\
\hline $\begin{array}{l}\text { Teoria nowej ekonomii } \\
\text { migracji (Stark, Bloom, } \\
\text { 1973) } \\
\text { poziom analizy: mikro/ } \\
\text { mezo }\end{array}$ & $\begin{array}{l}\text { Decyzje migracyjne podejmowane są w grupach } \\
\text { społecznych, zwłaszcza w ramach gospodarstwa } \\
\text { domowego; determinowane są przez rynek pracy, } \\
\text { system zabezpieczeń społecznych itp. Istotne } \\
\text { znaczenie ma poczucie relatywnej deprywacji } \\
\text { gospodarstw domowych. }\end{array}$ & $\begin{array}{l}\text { Skupienie na } \\
\text { czynnikach po stronie } \\
\text { kraju wysyłającego. }\end{array}$ \\
\hline
\end{tabular}


Tab. 1. Przegląd głównych teorii/modeli migracyjnych (cd.)

\begin{tabular}{|c|c|c|}
\hline $\begin{array}{l}\text { Teoria systemu } \\
\text { światowego } \\
\text { (Wallerstein, 1974; } \\
\text { Sassen, 1988) } \\
\text { poziom analizy: makro }\end{array}$ & $\begin{array}{l}\text { Migracje należy rozpatrywać z perspektywy } \\
\text { nierównych powiązań między krajami wysoko } \\
\text { rozwiniętymi i krajami rozwijającymi się. } \\
\text { W wersji teorii neokolonialnej podkreśla się } \\
\text { również istnienie silnych więzi historycznych, } \\
\text { gospodarczych i społecznych, co przejawia się } \\
\text { napływem migrantów z byłych kolonii do państw } \\
\text { kolonialnych. }\end{array}$ & $\begin{array}{l}\text { Niekiedy nadmierna } \\
\text { ideologizacja; } \\
\text { wyjaśnienia } \\
\text { formułowane } \\
\text { z ogólnego poziomu } \\
\text { teorii, często } \\
\text { niepoddawane testom } \\
\text { empirycznym. } \\
\end{array}$ \\
\hline $\begin{array}{l}\text { Teoria sieci } \\
\text { migracyjnych (Faist, } \\
\text { 2000; Vertovec, 2002) } \\
\text { poziom analizy: } \\
\text { mezo (sieci, diaspora) }\end{array}$ & $\begin{array}{l}\text { Migranci podążają ścieżkami wyznaczonymi } \\
\text { przez poprzednich migrantów. }\end{array}$ & $\begin{array}{l}\text { Pomijanie faktu, } \\
\text { że mogą istnieć } \\
\text { równoległe sieci } \\
\text { migracyjne (np. } \\
\text { rodzinna i zawodowa), } \\
\text { a ich skutki mogą się } \\
\text { wykluczać. }\end{array}$ \\
\hline $\begin{array}{l}\text { Teoria sieci społecznych/ } \\
\text { kapitału społecznego } \\
\text { (Granovetter, 1973; } \\
\text { Harvey, 2012) } \\
\text { poziom analizy: mezo/ } \\
\text { mikro }\end{array}$ & $\begin{array}{l}\text { Migranci korzystają z sieci społecznych } \\
\text { w poszukiwaniu pracy za granicą; znaczenie mają } \\
\text { nie tylko funkcjonowanie w danej sieci, lecz także } \\
\text { wartości w nią wpisane, strategiczne ulokowanie } \\
\text { i hierarchizacja. Słabe ulokowanie w sieciach } \\
\text { społecznych obniża szanse na znalezienie } \\
\text { odpowiedniej pracy nawet w przypadku wysoko } \\
\text { wykwalifikowanych migrantów. }\end{array}$ & $\begin{array}{l}\text { Przecenianie } \\
\text { znaczenia kontaktów } \\
\text { społecznych. }\end{array}$ \\
\hline $\begin{array}{l}\text { Teoria migracji } \\
\text { niepełnych (Okólski, } \\
\text { 2001) } \\
\text { poziom analizy: mikro }\end{array}$ & $\begin{array}{l}\text { Wielokrotne podejmowanie zatrudnienia } \\
\text { czasowego w innym państwie i regularne powroty } \\
\text { do państwa pochodzenia powodują podwójną } \\
\text { marginalizację migrantów (i w społeczeństwie } \\
\text { wysyłającym, i w przyjmującym). }\end{array}$ & $\begin{array}{l}\text { Zasadniczo wyjaśnia } \\
\text { migrację osób o niskim } \\
\text { i średnim poziomie } \\
\text { wykształcenia } \\
\text { i niewysokich } \\
\text { aspiracjach } \\
\text { zawodowych. }\end{array}$ \\
\hline
\end{tabular}

Źródło: opracowanie na podstawie: Włoch (2015: 24-26)

Modele migracji odnoszą się również do kwestii cech wrodzonych, wiedzy, umiejętności i doświadczenia osób podejmujących decyzje o przesiedleniu, jak również do rodzajów wykonywanych zawodów na rynku pracy czy środowiska, w którym funkcjonują imigranci.

W literaturze przedmiotu panuje pogląd, że w wymiarze ekonomicznym migracje są korzystne dla krajów przyjmujących imigrantów (Kahanec, Zimmermann, 2011). Napływająca ludność może stanowić cenny zasób, szczególnie w sytuacji pozyskiwania wysokich kwalifikacji, a tym samym (Włoch, 2015):

- przyczyniać się do wzrostu efektywności pracy w strategicznych sektorach (przez wzrost innowacyjności powodowany zróżnicowanym środowiskiem pracy),

- zwiększać możliwości ekspansji na rynki międzynarodowe (pracownicy-migranci dysponują wiedzą na temat specyfiki rynku kraju pochodzenia, znają język, uwarunkowania społeczno-kulturowe, polityczno-prawne),

- uzupełniać krajową podaż wykwalifikowanej siły roboczej. 
Rozumiejąc znaczenie procesów migracyjnych we współczesnej gospodarce (przez pozyskiwanie zasobów ludzkich według określonych kompetencji), państwa określają politykę, jaką będą stosować wobec imigrantów. W zakresie polityki imigracyjnej dla samozatrudnienia i przedsiębiorczości w krajach OECD (tab. 2), wśród kryteriów stosowanych przez te państwa można wymienić: posiadane doświadczenie, minimalne nakłady inwestycyjne, opracowanie planu działalności, znaczenie dla gospodarki czy ograniczenia dotyczące podejmowanych rodzajów działalności

Tab. 2. Przyjęte kryteria wobec polityki imigracyjnej dla samozatrudnienia i przedsiębiorczości w krajach OECD

\begin{tabular}{|l|l|l|}
\hline \multirow{2}{*}{ Kryteria } & \multicolumn{2}{|c|}{ Kraje wykorzystujące dane kryteria } \\
\cline { 2 - 3 } Doświadczenie & $\begin{array}{l}\text { Australia, Austria, Belgia, Kanada, } \\
\text { Dania, Finlandia, Niemcy, Grecja, } \\
\text { Irlandia, Włochy, Japonia, } \\
\text { Holandia, Nowa Zelandia, } \\
\text { Norwegia, Portugalia, Hiszpania, } \\
\text { Szwecja, Szwajcaria }\end{array}$ & $\begin{array}{l}\text { Australia, Kanada, Nowa Zelandia } \\
\text { (chyba że inwestycja jest powyżej } \\
\text { progu, gdzie nie jest wymagane } \\
\text { doświadczenie) }\end{array}$ \\
\hline Minimalna inwestycja & $\begin{array}{l}\text { Czechy, Nowa Zelandia, Wielka } \\
\text { Brytania (zazwyczaj zobowiązanie } \\
\text { do przedstawienia dowodu } \\
\text { posiadania środków finansowych na } \\
\text { wydatki i założenia działalności) }\end{array}$ & $\begin{array}{l}\text { Australia, Kanada, Francja, Grecja, } \\
\text { Irlandia, Korea Płd., Holandia, } \\
\text { Nowa Zelandia, Portugalia, } \\
\text { Hiszpania, Wielka Brytania, USA }\end{array}$ \\
\hline Business Plan & $\begin{array}{l}\text { Austria, Belgia, Dania, Finlandia, } \\
\text { Francja, Niemcy, Irlandia, Holandia, } \\
\text { Nowa Zelandia, Norwegia, Polska, } \\
\text { Hiszpania, Szwecja, Szwajcaria }\end{array}$ & Grecja, Irlandia, Holandia \\
\hline $\begin{array}{l}\text { Ograniczenie } \\
\text { działalności }\end{array}$ & $\begin{array}{l}\text { Australia, Kanada, Czechy, Dania, } \\
\text { Japonia }\end{array}$ & Australia, Korea Płd. \\
\hline $\begin{array}{l}\text { Znaczenie dla lokalnej } \\
\text { gospodarki }\end{array}$ & $\begin{array}{l}\text { Austria, Belgia, Dania, Finlandia, } \\
\text { Niemcy, Grecja, Irlandia, Holandia, } \\
\text { Polska, Szwajcaria }\end{array}$ & Grecja, Irlandia, Portugalia, USA \\
\hline
\end{tabular}

Źródło: opracowanie na podstawie: World migration report 2015 (IOM, 2015)

\section{Przedsiębiorczość imigrantów}

W Unii Europejskiej 6,6\% osób pracujących na własny rachunek (samozatrudnionych) urodziło się poza granicami kraju zamieszkania, co stanowi ponad $2 \mathrm{mln}$ osób, z czego 3,1\% stanowią osoby urodzone w krajach Unii Europejskiej, a 3,5\% to osoby urodzone poza UE (tab. 3).

W Estonii, Chorwacji, Słowenii, na Łotwie czy w Portugalii można dostrzec wśród przedsiębiorców imigrantów przewagę tych urodzonych poza granicami Unii. W Austrii, Irlandii czy Belgii większościową grupę stanowią imigranci z terenów innych krajów UE, a znaczną różnicę w tym zakresie można odnotować w przypadku Luksemburga, gdzie 44,6\% wśród przedsiębiorców imigrantów stanowią pochodzący z UE. Wskaźnik samozatrudnienia wśród osób urodzonych za granicą jest nieco niższy niż dla rodowitych mieszkańców: średnia 
dla UE wynosi w przypadku imigrantów 14,1\%, podczas gdy dla rdzennych mieszkańców $15,3 \%$ (ryc. 2).

Tab. 3. Struktura samozatrudnienia wśród imigrantów ze względu na pochodzenie z UE i spoza UE

\begin{tabular}{|l|c|c|c|}
\cline { 2 - 4 } \multicolumn{1}{c|}{} & Imigranci z UE & Imigranci spoza UE & $\begin{array}{c}\text { \% imigrantów wśród } \\
\text { samozatrudnionych } \\
\text { ogółem }\end{array}$ \\
\hline Węgry & 1,8 & 0,7 & 2,5 \\
\hline Grecja & 0,8 & 2,0 & 2,8 \\
\hline Łotwa & & 3,3 & 3,3 \\
\hline Finlandia & 2,0 & 2,1 & 4,1 \\
\hline Czechy & 1,8 & 2,4 & 4,2 \\
\hline Malta & 2,2 & 3,1 & 5,2 \\
\hline Estonia & & 5,5 & 5,5 \\
\hline Portugalia & 1,8 & 3,8 & 5,6 \\
\hline Chorwacja & 1,2 & 4,7 & 5,9 \\
\hline Słowenia & 0,8 & 5,6 & 6,4 \\
\hline EU28 & 3,1 & 3,5 & 6,6 \\
\hline Włochy & 2,7 & 4,2 & 7,0 \\
\hline Holandia & 3,0 & 4,9 & 7,9 \\
\hline Dania & 4,0 & 5,4 & 9,4 \\
\hline Francja & 3,7 & 6,1 & 9,8 \\
\hline Hiszpania & 5,2 & 4,7 & 9,9 \\
\hline Austria & 8,3 & 4,4 & 12,7 \\
\hline Szwecja & 5,9 & 7,3 & 13,2 \\
\hline Irlandia & 10,6 & 3,0 & 13,6 \\
\hline Belgia & 8,7 & 5,2 & 13,9 \\
\hline Wielka Brytania & 7,6 & 7,3 & 14,9 \\
\hline Cypr & 9,1 & 6,2 & 15,3 \\
\hline Luksemburg & 44,6 & 5,9 & 50,5 \\
\hline
\end{tabular}

Źródło: opracowanie własne na podstawie: Eurostat (2014), OECD/European Union (2015)

Zdecydowanie wyższy wskaźnik samozatrudnienia wśród rdzennych mieszkańców można zauważyć w takich krajach, jak Grecja, Włochy, Portugalia, Cypr, Hiszpania czy Irlandia. Natomiast wyższą aktywność w przypadku samozatrudnienia wśród imigrantów można odnotować m.in. w Polsce, Czechach czy Wielkiej Brytanii.

Porównywalne dane, dotyczące aktywności przedsiębiorczej wśród imigrantów w poszczególnych krajach, zostały zamieszczone w raporcie opracowanym w 2010 r. przez OECD, dotyczącym krajów należących do OECD, a więc również państw spoza UE (tab. 4). Na tej podstawie można zaobserwować wyższą i niższą skłonność do działań przedsiębiorczych w porównaniu z rodzimymi mieszkańcami w poszczególnych krajach, co skłania do poznania przyczyn tego zjawiska i staje się interesującym zagadnieniem badawczym.

Można przypuszczać, że na taki obraz wskaźników mają wpływ z jednej strony bariery przedsiębiorcze dla emigrantów (kapitał, koszty utrzymania czy ograniczenia formalno-prawne), a z drugiej strony skłonność rodzimych mieszkańców do prowadzenia własnej firmy (np. 


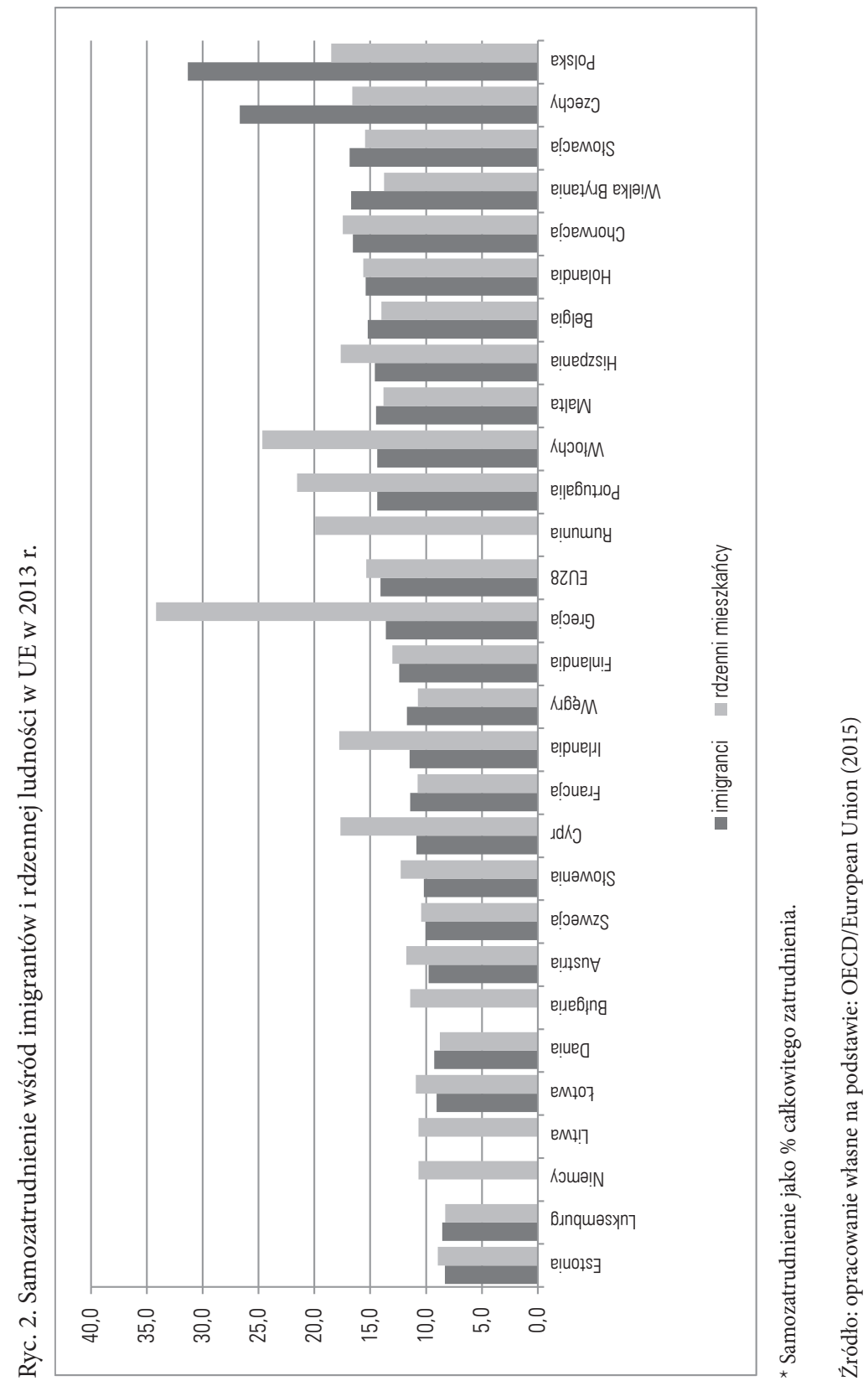


Grecja). Powstaje zatem pytanie, na ile występujące różnice są wynikiem zachowań przedsiębiorczych, na ile wynikają z ograniczeń formalno-prawnych, a na ile są wynikiem wymuszonej przedsiębiorczości.

Tab. 4. Wskaźnik samozatrudnienia wśród imigrantów i rdzennej ludności w krajach OECD w 2009 r.

\begin{tabular}{|l|c|c|}
\hline \multicolumn{1}{|c|}{ Kraj } & Ludność rdzenna & Imigranci \\
\hline Australia & $16,3 \%$ & $18,8 \%$ \\
\hline Austria & $9,3 \%$ & $8,4 \%$ \\
\hline Belgia & $12,1 \%$ & $15,5 \%$ \\
\hline Kanada & $14,5 \%$ & $17,5 \%$ \\
\hline Czechy & $15,3 \%$ & $19,6 \%$ \\
\hline Dania & $7,0 \%$ & $9,6 \%$ \\
\hline Finlandia & $9,6 \%$ & $14,1 \%$ \\
\hline Francja & $8,1 \%$ & $10,8 \%$ \\
\hline Niemcy & $10,0 \%$ & $9,5 \%$ \\
\hline Grecja & $26.4 \%$ & $10,6 \%$ \\
\hline Węgry & $10,8 \%$ & $16,4 \%$ \\
\hline Irlandia & $16,8 \%$ & $9,3 \%$ \\
\hline Włochy & $23,6 \%$ & $17,5 \%$ \\
\hline Luksemburg & $5,4 \%$ & $6,5 \%$ \\
\hline Holandia & $11,0 \%$ & $11,0 \%$ \\
\hline Norwegia & $5,8 \%$ & $6,9 \%$ \\
\hline Polska & $11,2 \%$ & $29,2 \%$ \\
\hline Portugalia & $15,6 \%$ & $12,1 \%$ \\
\hline Słowacja & $12,6 \%$ & $26,4 \%$ \\
\hline Hiszpania & $16,0 \%$ & $11,7 \%$ \\
\hline Szwecja & $8,5 \%$ & $10,0 \%$ \\
\hline Szwajcaria & $12,4 \%$ & $9,1 \%$ \\
\hline Turcja & $21,5 \%$ & $18,2 \%$ \\
\hline Wielka Brytania & $11,9 \%$ & $13,4 \%$ \\
\hline USA & $9,9 \%$ & $10,2 \%$ \\
\hline
\end{tabular}

Źródło: opracowanie na podstawie: OECD (2010b)

Według statystyk samozatrudnieni imigranci w Unii Europejskiej rzadziej zatrudniają pracowników w swoich firmach $(24,7 \%)$ w porównaniu z ludnością rdzenną $(28,5 \%)$ (Eurostat, 2014). Odstępstwa od tego unijnego trendu można jednak zauważyć w takich krajach, jak Czechy, Portugalia, Słowenia, Szwecja, Chorwacja, Łotwa i Węgry. W tym miejscu warto postawić sobie pytanie, czy nie są to kraje atrakcyjne do podejmowania działalności przez obywateli państw UE o wyższym standardzie życia, którzy pragną wykorzystać swój potencjał i przewagę, działając w kraju, gdzie rodzimi mieszkańcy mają mniejsze doświadczenie w biznesie, w wybranych branżach. Poznanie motywów migracji wśród przedsiębiorców imigrantów z uwzględnieniem ich narodowości oraz branży, w której działają w poszczególnych krajach, pozwoliłoby na formułowanie precyzyjnych wniosków. Niestety, brak jest spójnych i kompleksowych badań w tym zakresie. 
Przedsiębiorcy wywodzący się z grup imigrantów najczęściej podejmują działalność gospodarczą jako alternatywę dla zatrudnienia na stanowiskach o niskich wymaganiach kwalifikacyjnych na rynku pracy (Ndofor, Priem, 2011) lub w celu uniknięcia dyskryminacji na rynku pracy. Wielu imigrantów traktuje samozatrudnienie jako jeden z niewielu sposobów na osiągnięcie awansu społecznego (Marucci, Montedoro, 2010). Motywacje te wydają się sugerować, że imigranci-przedsiębiorcy mogli zostać „wepchnięci” (ang. pushed) do biznesu i dlatego mało prawdopodobne jest, by myśleli o rozwoju swoich firm. Z drugiej strony, imigranci mogą stanowić kluczowy czynnik w realizacji strategii internacjonalizacji, wynikający z łączenia i znajomości różnych kultur. Jak przypuszczają H. Ndofor i R. Priem (2011), przedsiębiorcy drugiego pokolenia imigrantów mogą przyczyniać się do wzrostu firm na arenie międzynarodowej.

\section{Podsumowanie - perspektywy rozwoju badań przedsiębiorczości wśród imigrantów}

Migracje ludności są faktem i z wysokim prawdopodobieństwem będą ulegały dalszej intensyfikacji. O ile motywy i kierunki migracji mogą być różne, o tyle bez wątpienia wymagają one podjęcia określonej aktywności wiążącej się z ryzykiem związanym z funkcjonowaniem w niepewnych warunkach. Podejmowanie takich działań charakteryzuje osoby przedsiębiorcze. Również zjawisko deprywacji, które towarzyszy imigrantom (rozłąka z rodziną, krewnymi, wykluczenie społeczne, bezpieczeństwo wynikające ze znajomości przepisów prawnych, a także bezpieczeństwo ekonomiczne), ma wiele wspólnego z umiejętnym funkcjonowaniem w zmieniających się warunkach. Zdolność do funkcjonowania w kontekście ciągłych zmian została dość dobrze rozpoznana w zakresie zarządzania zmianą, jak również w problematyce przedsiębiorczości i innowacyjności.

Połączenie tych dwóch nurtów badawczych: migracji i przedsiębiorczości stwarza interesujące pole badawcze. W literaturze przedmiotu można wprawdzie znaleźć badania dotyczące tej problematyki, jednak odczuwa się pewien niedosyt w tej kwestii, szczególnie chodzi tu o pogłębione, kompleksowe badania. Ograniczenia badawcze czasowo-ekonomiczne nie pozwoliły na analizę wielu interesujących aspektów w ramach poruszonej tematyki. Mogą one jednak stanowić podstawę do podjęcia pogłębionych badań, które pozwolą na uwzględnienie uwarunkowań w poszczególnych krajach.

W trakcie dalszych badań warto zatem podjąć próbę otrzymania odpowiedzi na następujące pytania:

- Jakie są czynniki wypychające po stronie państwa, z którego pochodzą emigranci?

- Jakie są czynniki przyciągające po stronie państwa, które determinują decyzję o podjęciu migracji do tego kraju?

- Jaka część cudzoziemców znajduje pracę w sektorze wysokich kwalifikacji, a jaka w sektorze o zapotrzebowaniu na niskie kwalifikacje?

- Jakie czynniki mogą utrudniać znajdowanie pracy w sektorze wysokich kwalifikacji?

- Jakie czynniki stanowią największą barierę w działaniach przedsiębiorczych?

- Czy występuje zjawisko „pułapki enklawy etnicznej”, tzn. podejmowania pracy w ramach danego środowiska etnicznego?

- Jakie są główne motywy przedsiębiorczości oraz pomysły na nią wśród imigrantów?

- W jakich branżach działają imigranci?

- Jakie są główne źródła finansowania działań przedsiębiorczych? 
- Czy imigranci są nastawieni na rozwój swoich firm?

- Czy imigranci w drugim pokoleniu dokonują internacjonalizacji firm?

Uzyskanie odpowiedzi na powyższe kwestie może być pomocne we wprowadzaniu skuteczniejszych działań w zakresie rozwoju przedsiębiorczości wśród imigrantów. Postępujące procesy globalizacyjne wymagają bowiem coraz bardziej przemyślanych i skoordynowanych działań uwzględniających migracje ludności. Działania te powinny przyczyniać się do łagodnej formy asymilacji napływającej ludności i dać imigrantom możliwości wykorzystania ich potencjału. W związku z tym wspieranie przedsiębiorczości może stać się jednym z efektywniejszych rozwiązań w przeciwdziałaniu wykluczeniu społecznemu.

\section{Literatura}

References

Ajzen, I. (1991). The theory of planned behavior. Organizational Behavior and Human Decision Processes, 50(2), 179-211.

Biuletyn Migracyjny (2016, 15 stycznia). Ośrodek Badań nad Migracjami UW. Pozyskano z: http://www. biuletynmigracyjny.uw.edu.pl

Clark, W.A.V. (1986). Human migration. Scientific Geography Series, 7.

Domurat, A. (2011). Przedsiębiorczość a kreatywność i innowacyjność. W: A. Strzałecki (red.), Innowacyjna przedsiębiorczość. Teorie. Badania. Zastosowania praktyczne. Perspektywa psychologiczna. Warszawa: Wydawnictwo SWPS „Academica”.

Drucker, P. (1991). Innowacja i przedsiębiorczość - praktyka i zasady. Warszawa: PWE.

Gibb, A.A. (1990). Enterprenurship and intrapreneurship - exploring the differences. W: R. Donckels, A. Miettinen (red.), New findings and perspectives in Entrepreneurship. Aldershot: Awebury Gower Publishing Group, 33-67.

Glinka, B., Gudkova, S. (2011). Przedsiębiorczość. Warszawa: Wolters Kluwer.

Holobinko, A. (2012). Theoretical and methodological approaches to understanding human migration patterns and their utility in forensic human identification cases. Societies, 2, 42-62. DOI: 10.3390/ soc2020042

Internetowa encyklopedia PWN (2015, 17 grudnia). Pozyskano z: http://www.encyklopedia.pwn.pl

IOM (2015). World migration report 2015, migrants and cities: New partnerships to manage mobility. France: International Organization for Migration.

Kahanec, M., Zimmermann, K. (2011). High-skilled immigration policy in Europe. DIW Berlin: Discussion Papers, 1096. DOI: 10.2139/ssrn.1767902

Konieczna-Sałamatin, J. (red.). (2015). Imigranci o wysokich kwalifikacjach na polskim rynku pracy. Badanie społeczne. Warszawa: Instytut Społeczno-Ekonomicznych Ekspertyz, Fundacja „Nasz Wybór".

Kosała, M. (2014). Badanie postaw przedsiębiorczych wśród młodzieży jako fundament kształtowania postawy odpowiadającej wyzwaniom współczesnego świata. Horyzonty Wychowania, 13(2), 317-340.

Kosała, M., Pichur, A. (2008). Analiza działań przedsiębiorczych i postrzeganie prowadzenia działalności gospodarczej wśród młodego pokolenia - wybrane aspekty. Przedsiębiorczość - Edukacja, $4,347-354$.

Lucassen, J., Lucassen, L., Mannin, P. (red.). (2010). Migration history in world history: Multidisciplinary approaches. Leiden and Boston: Brill.

Marucci, M., Montedoro, C. (2010). L'integrazione degli immigrati tra politiche attive del lavoro e politiche sociali: esperienze ed eccellenze in quattro regioni italiane. Strumenti ISFOL, 6. W: The missing Entrepreneurs 2015: Policies for self-employment and Entrepreneurship. Paris: OECD Publishing. DOI: $10.1787 / 9789264226418$-en 
Ndofor, H., Priem, R. (2011). Immigrant Entrepreneurs, the ethnic enclave strategy, and venture performance. Journal of Management, 37(3), 790-818.

OECD (2010a). Entrepreneurship and migrants. Report by the OECD working party on SMEs and Entrepreneurship. Paris: OECD Publications.

OECD (2010b). Open for business: migrant Entrepreneurship in OECD countries. Paris: OECD Publishing. DOI: $10.1787 / 9789264095830$-en

OECD (2015). The missing Entrepreneurs 2015: Policies for self-employment and Entrepreneurship. Paris: OECD Publishing.

Piasecki, B. (1997). Przedsiębiorczość i mała firma - teoria i praktyka. Łódź: Wydawnictwo Naukowe UŁ. Targalski, J., Kosała, M., Pichur, A. (2007). Postawy przedsiębiorcze wśród studentów kierunku ekonomia Akademii Ekonomicznej w Krakowie - analiza wyników badań. W: P. Wachowiak, M. Dąbrowski, B. Majewski (red.), Ksztattowanie postaw przedsiębiorczych a edukacja ekonomiczna. Warszawa: Fundacja Promocji i Akredytacji Kierunków Ekonomicznych, 90-100.

Wach, K. (2013). Edukacja na rzecz przedsiębiorczości wobec współczesnych wyzwań cywilizacyjno-gospodarczych. Przedsiębiorczość - Edukacja, 8, 246-257.

Wach, K. (2015a). Przedsiębiorczość jako czynnik rozwoju społeczno-gospodarczego: przegląd literatury. Przedsiębiorczość - Edukacja, 11, 24-36.

Wach, K. (2015b). Środowisko biznesu rodzinnego jako stymulanta intencji przedsiębiorczych młodzieży akademickiej. Przedsiębiorczość i Zarządzanie, 16(7/3), 25-40.

Włoch, R. (2015). Przegląd literatury przedmiotu i badań empirycznych. W: J. Konieczna-Sałamatin (red.), Imigranci o wysokich kwalifikacjach na polskim rynku pracy. Badanie społeczne. Warszawa: ISEE, Fundacja „Nasz Wybór”, 17-60.

Małgorzata Kosała, dr, adiunkt w Katedrze Przedsiębiorczości i Innowacji na Wydziale Ekonomii i Stosunków Międzynarodowych Uniwersytetu Ekonomicznego w Krakowie. Jej zainteresowania badawcze koncentrują się wokół problematyki procesów innowacyjnych, potencjału innowacyjnego przedsiębiorstw, uwarunkowań innowacyjności, kreatywności, zarządzania oraz szeroko rozumianej przedsiębiorczości ze szczególnym uwzględnieniem sektora małych i średnich przedsiębiorstw. Jest autorką ponad 40 krajowych i zagranicznych publikacji naukowych. Jako pracownik naukowo-dydaktyczny Uniwersytetu Ekonomicznego brała udział w wielu pracach badawczych.

Małgorzata Kosała, $\mathrm{PhD}$, assistant professor at the Cracow University of Economics - Department of Entrepreneurship and Innovation. Her scientific interests focus on innovation process issues, innovative potential of enterprises, conditions for innovativeness, management and entrepreneurship especially in small and medium-sized enterprises. $\mathrm{PhD}$ in management within the specialization of innovation management (2006), Master in Organization and Management. She is a member of the Scientific Committee of the National Entrepreneurship Contest.

\section{Adres/Address:}

Uniwersytet Ekonomiczny w Krakowie

Katedra Przedsiębiorczości i Innowacji

ul. Rakowicka 27

31-510 Kraków, Polska

e-mail: kosalam@uek.krakow.pl

Artykuł powstał w ramach projektu badawczego nr 054/WE-KPI/02/2015/S/5054 pt. „Przedsiębiorczość inkluzywna: współczesne wyzwania i perspektywy rozwoju”, sfinansowanego ze środków przyznanych Wydziałowi Ekonomii i Stosunków Międzynarodowych Uniwersytetu Ekonomicznego w Krakowie, w ramach dotacji na utrzymanie potencjału badawczego. 